\title{
STRATEGI PENELITIAN KUALITATIF DAN KUANTITATIF DI DALAM PENELITIAN AGAMA
}

\author{
Sonny Eli Zaluchu \\ Pascasarjana Sekolah Tinggi Teologia Baptis Indonesia (STBI) Semarang \\ Jln. Simongan No. 1 Pusponjolo Selatan - Semarang 50141 - Jateng - Indonesia \\ Email: sonnyzaluchu@stbi@ac.id
}

\begin{abstract}
Research does not start from the method but must depart from the root of the problem. Formulating precisely the paradigm and background of the research will help researchers design the research design and determine the method to use. In this case, quantitative, qualitative or a mixture of both can use. Through this paper, it explains that religious research and various topics within it are open with various approaches because of their nature as science. This paper builds research insights ranging from understanding the research itself, determining and formulating research problems to choosing the right approach by introducing various methods. Through this paper, it expected that there would be no difficulty in colliding the paradigm in conducting religious research with a qualitative, quantitative or both approaches.
\end{abstract}

Keywords:Research, Qualitative, Quantitative, Religion

\begin{abstract}
ABSTRAK: Penelitian tidak dimulai dari metode tetapi harus berangkat dari akar permasalahan. Merumuskan secara tepat paradigma dan latar belakang penelitian akan membantu peneliti merancang desain penelitian dan menentukan metode yang akan digunakan. Dalam hal ini, dapat digunakan pendekatan kuantitatif, kualitatif atau campuran keduanya. Melalui tulisan ini dipaparkan bahwa penelitian agama dan berbagai topik di dalamnya terbuka dengan berbagai pendekatan karena sifatnya sebagai ilmu pengetahuan. Paper ini membangun wawasan penelitian mulai dari pemahaman tentang penelitian itu sendiri, penentuan dan perumusan masalah penelitian hingga memilih pendekatan yang tepat melalui perkenalan terhadap berbagai metode. Melalui paper ini diharapkan tidak terdapat kesulitan benturan paradigma di dalam menjalankan penelitian agama dengan pendekatan kualitatif, kuantitatif atau keduanya.
\end{abstract}

Kata Kunci: Riset, Kualitatif, Kuantitatif, Agama

\section{PENDAHULUAN}

Penelitian berasal dari 'research' yang dalam bahasa Indonesia disebutriset (Booth, Colomb, \& Williams, 2008, p. 10). Kamus Merriam-Webster online menerjemahkan kata itu sebagai tindakan pencarian yang dilakukan secara cermat dan hatihati. Juga diartikan sebagai usaha penyelidikan atau pemeriksaan yang cermat; melalui sebuah investigasi atau percobaan yang bertujuan menemukan dan menafsirkan fakta tertentu (Merriam-Webster Dictionary Online, 2019). Oleh sebab itu, sebuah penelitian memenuhi standar empirik-sistematis sebagaimana diungkapkan oleh Ruane (2013, pp. 18-20), mencakup empat tujuan dasar yakni: eksplorasi, deskripsi, eksplanasi dan evaluasi. Eskplorasi adalah riset yang diadakan untuk menjadi tahu atau mening- katkan pemahaman. Sementara itu, deskrispsi memberikan gambaran atau laporan rinci mengenai fenomena. Jika penelitian dipusatkan pada analisis kausal (sebab akibat) maka riset mengarah pada eksplanasi. Jika penelitian dilakukan untuk menilai baik-buruknya sebuah fenomena, maka terjadilah penelitian evaluasi. Merujuk definisi yang dibangun oleh Vyhmeister (2001, p. 1), penelitian adalah sebuah studi yang mana melaluinya dilakukan investigasi yang cermat dan sistematis secara ilmiah, terhadap semua bukti atau data menyangkut masalah tertentu, untuk akhirnya menghasilkan sebuah solusi. Karena mencakup sebuah studi ilmiah, maka penelitian memerlukan langkah-langkah tertentu yang sistematis. Ilmu tentang hal ini disebut sebagai Metodologi Penelitian. Sedangkan langkah-langkah atau cara melaksa- 
nakan penelitian secara sistematis didefinisikan sebagai Metode Penelitian (Silalahi, 2018, pp. 2-7).

Salah satu masalah di dalam penelitian agama adalah perdebatan mengenai pendekatan yang tepat terhadap penelitian agama, apakah mengarah pada pendekatan kualitatif atau dapat juga dilakukan secara kuantitatif (Lumintang \& Lumintang, 2016, p. 6). Hal ini terjadi karena peneliti memulainya dengan metode dan tidak menjadikan pokok penelitian sebagai dasar. Untuk membantu membentuk paradigma dan langkah-langkah yang tepat di dalam penelitian agama, paper ini disusun. Dengan demikian, peneliti diharapkan mampu merumuskan metode penelitian bagi setiap penelitian agama yang dijalankan setelah terlebih dahulu menetapkan pokok permasalahan. Sebab, sebuah penelitian yang baik seharusnya berangkat dari masalah yang menjadi pokok penelitian dan bukan pada metodenya (Zaluchu, 2019, p. 15). Metode mengikuti masalah.

\section{METODE}

Paper ini ditulis secara deskriptif (Nassaji, 2015) untuk memberikan uraian yang mengarah pada pembentukan wawasan kualitatif dan kuantitatif di dalam penelitian agama. Ketegasan terhadap wawasan mutlak diperlukan karena kualitatif dan kuantitatif hanyalah metode bagi penelitian yang dijalankan. Hal pertama yang harus ditentukan bukanlah metode melainkan topik penelitian. Berdasarkan topik tersebut peneliti akan mengambil keputusan untuk memilih metode penelitiannya. Oleh karena itu, sebagai studi yang disusun dari bahan-bahan literatur (Knopf, 2006; Winchester \& Salji, 2016), pembahasan pertama-tama diarahkan pada pembentukan wawasan yang benar tentang penelitian, kemudian penentuan masalah di dalam riset dan diakhiri dengan paradigma metode penelitian. Penekanan diutamakan pada pembahasan tentang penemuan dan perumusan masalah penelitian. Sebab, hal inilah yang akan mengarahkan keputusan peneliti untuk memilih metode, apakah kualitatif atau kuantitatif (Creswell, 2009; Magnan \& Creswell, 2006).

\section{PEMBAHASAN}

\section{Paradigma Penelitian}

Menurut Carey (2015), sebuah penelitian di dalam metode apapun yang dipilih untuk menjalankannya setidaknya memenuhi unsur pengamatan, pengujian dan penjelasan. Semua itu diarahkan pada satu titik yakni mengungkapkan kebenaran. Penelitian yang baik dan berhasil adalah penelitian yang menemukan, menggali dan menghasilkan kebenaran. Tanpa kebenaran, maka penelitian tersebut adalah sebuah kegagalan (Golafshani, 2003).

Metode penelitian bervariasi. Tergantung dari keputusan peneliti berdasarkan pertimbanganpertimbangan rasional dalam memilih metode penelitiannya. Metode apapun yang akhirnya dipilih, sebuah penelitian berangkat dari pertanyaan dasar, mengapa dan untuk apa penelitian dilakukan. Banyak kajian telah dipaparkan oleh para ahli mengenai rumusan yang tepat tentang metode penelitian. Kamus Bahasa Indonesia online menjelaskan bahwa metode artinya cara teratur yang digunakan untuk melaksanakan suatu pekerjaan agar tercapai sesuai dengan yang dikehendaki; juga diartikan sebagai sebuah cara kerja yang bersistem untuk memudahkan pelaksanaan suatu kegiatan guna mencapai tujuan yang ditentukan (KBBI, 2017a). Sedangkan, menurut rujukan kamus yang sama, mendefinisikan penelitian sebagai pemeriksaan yang teliti; penyelidikan; kegiatan pengumpulan, pengolahan, analisis, dan penyajian data yang dilakukan secara sistematis dan objektif untuk memecahkan suatu persoalan atau menguji suatu hipotesis untuk mengembangkan prinsip-prinsip umum(KBBI, 2017b).

Dari sini dapat disimpulkan bahwa sebuah metode penelitian adalah rangkaian prosedur kerja ilmiah yang dilakukan sistematis, terarah dan objektif di dalam rangka memecahkan masalah penelitian. Rangkaian yang dimaksud dimulai dari saat rancangan penelitian mulai disusun, pengumpulan dan analisis data, pembuatan laporan hingga pada implikasi. Saebani menambahkan bahwa, metode penelitian adalah metode yang digunakan dalam aktifitas 
penelitian, misalnya metode penelitian kuantitatif atau kualitatif, metode penelitian deskriptif, studi kasus dan eksploratif (Saebani, 2015, p. 182). Ditambahkannya, sebuah penelitian merupakan aktifitas yang bertujuan menyelidiki seluk-beluk sesuatu yang menjadi masalah sehingga diperoleh kesimpulan-kesimpulan tertentu. Untuk itu diperlukan metode-metode tertentu dalam melakukan penelitian. Inilah yang disebutnya sebagai metode penelitian. Sedangkan, ilmu tentang metode penelitian adalah metodologi penelitian (Saebani, 2015). Dengan kata lain, metode penelitian adalah metode yang dipakai untuk menjalankan penelitian itu sendiri sedangkan metodologi penelitian adalah cakupan keilmuan tentang metode penelitian (Mackenzie \& Knipe, 2006).

\section{Menentukan Masalah Riset}

Sebuah penelitian dimulai dari masalah (Walliman, 2011). Pada umumnya, sumber masalah dapat dibagi dalam dua kategori yakni pengalaman empiris dan deduksi teoritis. Masalah yang muncul dari pengalaman empiris difokuskan untuk menemukan jawaban dari realitas-realitas yang membutuhkan jawaban, untuk menjawab pertanyaan-pertanyaan dari fenomena yang berlangsung di lapangan. Sementara itu, masalah yang bersumber dari deduksi teoritis berbasis pada teori-teori yang sudah ada sebelumnya untuk kemudian diteliti aplikasinya secara empiris, diuji dan disimpulkan apakah teori tersebut tetap (tidak berubah) atau perlu dikoreksi. Hasilnya dapat menguatkan atau melahirkan paradigma teori yang baru.

Masalah dan penyelesaian masalah adalah fondasi dari sebuah penelitian. Untuk mengkaji hal tersebut, peneliti dapat menempuhnya dengan berbagai pendekatan yang berbeda sesuai kebutuhan. Untuk itulah, peneliti dituntut memilih metode penelitian yang tepat, khususnya yang berkaitan dengan usaha mencari jawaban dari masalah yang ada. Creswell memberikan argumentasi bahwa masalah-masalah tertentu ikut memberi andil dalam menentukan jenis penelitian yang digunakan peneliti (Creswell, 2010, p. 29).
Penelitian berangkat dari sebuah masalah yang ingin diketahui bagaimana terjadinya dan solusi apa yang dapat menyelesaikannya. Masalah juga dapat memberikan gambaran tentang situasi atau fakta empiris dari sebuah fenomena, dimana akhirnya ditarik sebuah kesimpulan tentang fakta tersebut menjadi sebuah kebenaran ilmiah.

Masalah penelitian dapat didekati dari dua sisi. Pendekatan pertama adalah secara deduktif sedangkan pendekatan kedua adalah secara induktif (Heit \& Rotello, 2010; Lawson, 2005). Dalam cara deduktif, konsep dan teori digunakan sebagai pangkal penelitian yang menjelaskan gejala atau fenomena yang ada. Dari sana penelitian dilakukan untuk menguji apakah fenomena yang dijelaskan melalui teori tersebut sudah tepat adanya atau menghasilkan temuan baru yang sifatnya implikatif. Alur berpikir induktif adalah kebalikan dari cara berpikir deduktif. Induktif bertitik tolak dari 'pengamatan empirik' untuk kemudian melalui proses pengukuran dan pengujian dan akhirnya melahirkan sebuah kesimpulan atau teori atau sesuatu yang baru. Pilihan untuk memilih metode berpikir berada di tangan peneliti. Harus disadari bahwa setiap metode berpikir mengandung implikasi dan cara kerja yang berbeda satu dengan yang lain. Kebanyakan metode induktif menggunakan pendekatan kualitatif sedangkan metode deduktif menggunakan pendekatan kuantitatif.

Sebuah penelitian yang baik, haruslah berangkat dari masalah. Itu sebabnya di dalam setiap penelitian, selalu dimulai dari latar belakang masalah penelitian. Masalah muncul akibat terjadi perbedaan antara fakta empiris (lapangan atau kenyataan) dengan kebenaran teoritis atau harapan. Bisa berasal dari pengamatan atau justifikasi sepihak berdasarkan pengamatan atau pengalaman pribadi. Maka di dalam sebuah penelitian, sebuah masalah yang hadir untuk diteliti menuntut untuk dipaparkan, dianalisis dan dipecahkan melalui langkah-langkah yang dapat dipertanggungjawabkan. Dengan demikian, tidak semua masalah menjadi topik penelitian. Peneliti dituntut untuk menyaring dan melakukan seleksi terhadap semua identifikasi masalah menyangkut topik 
penelitian, sehingga hanya masalah-masalah yang relevan dengan tujuan penelitian saja yang dipergunakan sebagai landasan penelitian. Pembatasan masalah adalah usaha yang dilakukan peneliti untuk mempersempit lingkup penelitian dan mengarahkannya pada tujuan penelitian yang seharusnya. Tanpa batasan masalah maka penelitian akan bisa, tidak terarah dan memiliki terlalu banyak variabel.

Sebuah masalah penelitian yang baik haruslah menarik, menantang untuk dicari solusinya, menghasilkan perbaikan atau peningkatan ke arah sesuatu yang baik, membawa kepada sesuatu yang baru dan mencerahkan. Itu sebabnya di dalam sebuah penelitian, latar belakang masalah harus benarbenar mengungkapkan argumen yang pas bahwa fenomena yang sedang diteliti tersebut memang patut dan layak untuk diteliti melalui sebuah metode penelitian.

Di dalam latar belakang masalah, peneliti memaparkan argumentasi tentang latar belakang penelitian dan mengapa memilih topik atau fenomena tertentu sebagai pokok penelitian. Secara sederhana, latar belakang masalah adalah uraian yang memberikan penjelasan mengapa sebuah pokok tertentu dijadikan bahan penelitian. Di dalam uraian tersebut peneliti mengemukakan alasan-alasannya baik secara objektif maupun subjektif. Secara objektif artinya, peneliti menggunakan topik penelitian yang sudah ada sebelumnya atau teori tertentu menyangkut topik penelitiannya. Jika alasan ini yang muncul maka peneliti perlu memberikan referensi objektif berupa hasil-hasil penelitian di bagian awal latar belakang masalah, atau membeberkan secara singkat tinjauan pustaka yang berkaitan dengan topik penelitian yang sedang dibicarakan. Sedangkan secara subjektif artinya peneliti memiliki keterkaitan langsung dengan objek penelitian. Dalam hal ini, peneliti memiliki pengalaman tertentu menyangkut topik penelitian yang dibicarakan. Pengalaman peneliti dapat berangkat dari fakta empiris di lapangan, kenyataan atau masalah-masalah yang dihadapi, pengamatan kritis, sehingga memicu keinginan untuk diteliti lebih lanjut.
Kebanyakan latar belakang penelitian teologis dibangun dengan alasan subjektif.

Natur dari sebuah riset adalah masalah. Untuk memulainya dapat dilakukan dengan menetapkan atau merumuskan apa sebetulnya yang menjadi pokok penelitian yang dipermasalahkan. Misalnya terhadap pokok penelitian tentang Pelayanan Publik, peneliti perlu menguraikan secara sistematis aspekaspek yang menjadi masalah di dalam pokok tersebut. Tentu saja, agar uraian tentang latar belakang masalah itu mengalir dengan lancar, maka peneliti perlu merenungkan, mempelajari, memikirkan, melakukan berbagai kajian tentang pokok permasalahan yang diteliti secara runtut dan sistematis sehingga orang yang membacanya mengerti bahwa pokok tersebut memang layak untuk diteliti dan memiliki alasan kuat untuk diangkat sebagai bahan penelitian. Hal-hal yang patut direnungkan adalah sebagai berikut:

- Apakah pokok permasalahan tersebut menarik untuk diteliti.

- Apakah sebuah pokok permasalahan, benar-benar hadir sebagai sebuah masalah yang layak atau patut diteliti (bukan dibuat-buat).

- Apakah pokok permasalahan yang diteliti tersebut setelah diteliti menyumbangkan implikasi yang membawa penyelesaian, perbaikan atau pencerahan.

- Apakah terdapat sebuah kesenjangan antara kondisi ideal dari pokok permasalahan dengan realitas menyangkut pokok permasalahan tersebut sehingga layak diselidiki penyebabnya.

Peneliti dapat juga mengangkat di dalam latar belakang masalah mengenai hal-hal tertentu yang akhirnya menyebabkan peneliti tertarik melakukan kajian atas topik yang dipilih tersebut. Selain fakta empirik, hasil penelitian sebelumnya, dapat juga dipakai sebagai argumen latar belakang untuk menjelaskan ketertarikan peneliti. Khususnya mengenai keterlibatan variabel baru atau melalui pendekatan riset yang berbeda. Tujuannya bersifat mendalami temuan, menggugat, memperkuat atau mengoreksi hasil temuan orang lain. Itu sebabnya, kondisi ideal 
sebuah latar belakang masalah, dapat dilengkapi bukan hanya semata-mata dari pendekatan teoretis tetapi juga berasal dari kajian penelitian orang lain atau sumber-sumber ilmiah lainnya yang dapat dipertanggung-jawabkan kebenarannya. Dalam tahap ini, peneliti ditantang untuk menyampaikan argumentasi yang kuat mengapa harus memilih penelitian tersebut.

Bagaimana kedudukan variabel bebas di dalam latar belakang masalah? Seperti dikemukakan sebelumnya, latar belakang masalah adalah uraian menyeluruh tentang pokok permasalahan dan hal itu secara dominan menyangkut variabel terikat (Y). Latar belakang adalah uraian panjang lebar yang argumentatif tentang pokok masalah (Y) (Kothari, 2004). Termasuk di dalam uraian itu, sejumlah faktor yang diidentifikasi sebagai penyebab 'pokok penelitian' (Y) dan kita menyebutnya sebagai variabel bebas (X), harus deskripsikan. Di dalam latar belakang masalah peneliti menjelaskan hubungan-hubungan yang mungkin terjadi antara pokok penelitian dan penyebabnya, sehingga tercipta gambaran komprehensif tentang argumentasi pokok penelitian dan penyebab-penyebabnya. Tentu saja faktor-faktornya akan lebih dari satu. Peneliti perlu memberi proporsi yang seimbang dalam mendaftar dan menguraikan keberadaan faktor-faktor tersebut di dalam penjelasan di latar belakang masalah. Tujuan utamanya adalah agar pembaca mengerti keterkaitan antara pokok penelitian dengan variabel-variabel yang mempengaruhinya. Hal ini juga diperlukan untuk membantu peneliti merumuskan dan menyusun identifikasi masalah dan membebaskannya dari kebingungan merumuskan atau menentukan topik penelitian (Degeng \& Darmawan, 2017).

\section{Pemilihan Metode}

\section{Pendekatan Kuantitatif atau Kualitatif}

Kuantitatif atau kualitatif adalah pembagian metode penelitian berdasarkan pendekatan yang dilakukan oleh peneliti. Tetapi akhir-akhir ini, para ahli telah memadukan kedua pendekatan tersebut de- ngan memakai kedua metode bersama-sama dalam fungsi masing-masing dalam sebuah mixedmethodology. Buku-buku mengenai perpaduan kedua pendekatan ini sudah mulai muncul.

Pendekatan kuantitatif dan kualitatif dalam sebuah penelitian, pada umumnya dibedakan dari sumbernya. Paradigma ilmiah yang bersumber dari pandangan positivisme menjadi rujukan paradigma penelitian kuantitatif. Sedangkan paradigma ilmiah yang bersumber dari pandangan fenomenologis, menjadi dasar pijakan pendekatan kualitatif. Kedua pendekatan ini punya kelebihan dan kekurangan sehingga tidak jarang dipakai berdua oleh para peneliti dalam sebuah mixedmethodology (Brannen, 2005).

Demikian halnya pada sifat penelitian, pendekatan kualitatif lebih mengarah pada penyelidikan kebenaran yang bersifat relatif, hermenetik dan interpretatif. Pilihan pada pendekatan ini lebih banyak menggunakan analisis teori, dan hermenetik yang kuat untuk sampai pada sebuah kesimpulan. Sedangkan pendekatan kuantitatif lebih menekankan aspek behavioristik dan empiris yang berasal dari fenomena-fenomena di lapangan atau berdasarkan tingkah laku di lapangan, yang kemudian dijadikan patokan penelitian.

Dilihat dari instrumen penelitian yang menjadi alat pengumpulan data serta analisis, penelitian kualitatif banyak menggunakan data yang bersifat deskriptif seperti daftar wawancara, laporan hasil pengamatan lapangan, transkrip-transkrip pembicaraan, dan catatan-catatan pengamatan. Laporan disusun dari rangkuman semua sumber-sumber tersebut dengan dukungan teori yang ada, menjadi uraian analisis. Tahap analisis dalam pendekatan ini sudah dimulai sejak penelitian dan data pertama telah diperoleh. Sedangkan penelitian kuantitatif menggunakan angket dan data-data yang berupa angka, tabulasi, perhitungan-perhitungan menggunakan sejumlah metode analisis matematik/statistik yang hasilnya menjadi dasar pijakan untuk mengambil keputusan atau kesimpulan. Data dari pendekatan kuantitatif lebih banyak berbentuk angka dan tabel. Sementara itu, tahap analisis hanya dapat dilakukan jika data te- 
lah terkumpul dengan lengkap dan tersaji dalam tabulasi yang siap diolah secara statistik (Slevitch, 2011).

Dilihat dari tujuan yang hendak dicapai, penelitian kualitatif dilakukan untuk memahami fenomena empiris, khususnya mencari gambaran yang sebanyak-banyaknya tentang fenomena tersebut tanpa memerincinya dalam hubungan antar variabel yang saling terkait. Tujuan akhir yang dihasilkan adalah sebuah teori. Sedangkan penelitian kuantitatif, dilakukan untuk menguji dan membuktikan bahwa gambaran sebuah fenomena yang dirumuskan dalam bentuk variabel-variabel terbukti benar atau tidak benar dari teori yang telah diyakini selama ini. Hubungan antar variabel menjadi sesuatu yang sangat penting dan diutamakan.

Secara ringkas, perbedaan antara keduanya disajikan dalam tabel di bawah ini (Cooper \& Schindler, 2014, p. 147; Zaluchu, 2019, p. 20).

\begin{tabular}{|l|l|l|}
\hline Perbedaan & Kualitatif & Kuantitatif \\
\hline Pendekatan & Induktif & Deduktif \\
\hline Analisis & Sejak awal penelitian & Data terkumpul semua \\
\hline Bentuk Data & Deskriptif & Angka \\
\hline Hipotesis & Tidak perlu & Perlu dan sistematik \\
\hline Eksegesa & Ya & Ya dan Tidak \\
\hline Statistik & Ya sebatas desktiptif & Total diperlukan \\
\hline Alat pengumpulan Data & $\begin{array}{l}\text { Wawancara, Laporan } \\
\text { Pengamatan, dll }\end{array}$ & Angket terstruktur \\
\hline Sifat & Relatif, Eksegesa & Empiris, Behavioristik \\
\hline Hasil & Sempit makna, & Dapat digeneralisasi \\
\hline Tujuan & $\begin{array}{l}\text { Mencari hencari hubungan, } \\
\text { menemukan teori, } \\
\text { untuk memahami } \\
\text { fenomena } \\
\text { menguji, } \\
\text { memperoleh penjelasan }\end{array}$ \\
\hline Sampel & Sedikit (perorangan) & $\begin{array}{l}\text { Banyak (populasi dan } \\
\text { sampel) }\end{array}$ \\
\hline
\end{tabular}

Tabel 1. Perbandingan Metode Kualitatif dan

\section{Kuantitatif}

Berdasarkan tabel tersebut, maka metode penelitian terbagi dua. Metode penelitian yang tergolong dalam penelitian kualitatif adalah: Metode Etnografi, Studi Dokumen atau Teks, Pengamatan Alami, Studi Kasus, Hermeneutik, Grounded Theory dan Fenomenologi. Sedangkan metode penelitian yang tergolong dalam penelitian kuantitatif adalah: Metode Survey, Kausal Komparatif, Korelasional, Evaluasi dan Pengamatan Sistemik.

\section{Metode Penelitian menurut Tingkat Eksplanasi}

Berdasarkan tingkat eksplanasinya, metode penelitian dibagi dalam tiga kategori yakni Deskriptif, Eksploratori, dan Eksplanatori.

Metode penelitian deskriptif (descriptive research) pada umumnya bersifat memaparkan hasil penelitian dan variabel-variabel di dalam penelitian secara akurat. Pemaparan pada umumnya menyangkut variabel di dalam penelitian, sehingga diperoleh sajian informasi yang lengkap mengenai setiap variabel tersebut berdasarkan kategori yang telah ditetapkan peneliti sebelumnya. Penjelasan mengenai karakteristik atau sifat dari sebuah fenomena yang menjadi pokok penelitian menjadi ciri khas metode ini. Pilihan terhadap metode deskriptif pada umumnya dipakai jika peneliti ingin membeberkan informasi mengenai permasalahan yang sedang diteliti. Sejumlah alat dapat dipakai untuk menjelaskan seperti tabel, grafik, gambar dan bagan. Tujuan utamanya adalah mempertegas situasi atau kondisi tertentu (Neuman, 2016, p. 44; Sudaryono, 2018, p. 82).

Metode penelitian eksploratori (exploratory research) bersifat menggali dan mendalami. Lebih daripada sekedar mendeskripsikan. Juga bersifat menjajaki temuan dan menjelajahi setiap kemungkinan yang ada karena pengetahuan awal tentang masalah masih minim bahkan tidak ada. Penyelidikan diarahkan untuk menemukan masalah dan penyebabnya serta mencari ide atau hubungan yang baru yang selama ini belum terjelaskan. Teori dan kesimpulan yang dihasilkan bersifat tentatif dan memberi peluang untuk diuji pada penelitian lanjutan. Hanya saja, jenis penelitian ini bersifat terbuka dan sifat penjelajahannya yang luas membuat metode ini seperti tanpa arah. Jenis penelitian ini banyak digunakan pada studi kasus dan fenomena-fenomena sosial dalam ilmu humaniora. Sifatnya yang kreatif, fleksibel dan terbuka menjadikan penelitian ini terbuka terhadap semua sumber informasi(Aaker, Kumar, \& Day, 2003, p. 75; Neuman, 2016, p. 44).

Kebalikan dari metode eksploratori adalah penelitian eksplanatori (explanatory research). Penelitian ini bukan lagi menjajaki tetapi bersifat menjelaskan atau menerangkan. Kalau deskriptif men- 
jawab pertanyaan 'apa' maka eksplanatori menjawab pertanyaan 'mengapa' dan 'bagaimana' di dalam masalah penelitian. Hal ini dapat terjadi karena bahan dan data menyangkut masalah penelitian sudah lengkap sehingga menjadi bahan kajian. Penelitian ini bertujuan menguji hipotesis untuk menguatkan atau melemahkannya, bahkan menggugurkannya melalui teori-teori yang ada dan bahan-bahan empiris lainnya. Dalam metode ini hubungan-hubungan antara variabel di dalam model penelitian dianalisis sifatnya dan saling mempengaruhinya. Kesimpulan yang muncul dapat memperkuat atau menggugurkan hasil yang telah diperoleh dalam penelitian sebelumnya melalui analisis yang akurat. Oleh karena itu, penelitian eksplanatori juga disebut sebagai penelitian konfirmatori (confirmatory research) dan makin dikenal sebagai penelitian korelasional (correlational research) sehingga kadang kala muncul istilah confirmatory-explanatory research (Neuman, 2016, p. 44; Sudaryono, 2018, p. 82).

Penelitian eksplanasi (atau eksplanatori) memiliki dua tipe yakni penelitian asosiasi yang dikenal juga dengan nama penelitian kovariasional, dan penelitian kausal atau disebut juga dengan kausalkomparatif. Kedua tipe ini berkaitan dengan eksplanasi hubungan antar variabel di dalam model penelitian. Apabila hubungan antara variabel tidak saling menjelaskan sebab-akibat, maka tipe eksplanatorinya adalah asosiasi. Tetapi apabila, penelitian diarahkan untuk membuktikan hubungan sebab-akibat atau hubungan mempengaruhi-dipengaruhi antar variabel serta membandingkan hubungan itu satu sama lain, maka riset eksplanatorinya termasuk di dalam kategori kausal atau sering juga dinamakan kausalkomparatif. Dalam lingkup penelitian ini, berbagai variabel dapat dilihat hubungan dan saling pengaruhnya, kecenderungannya dan sifat-sifat yang muncul antara variabel bebas dan variabel terikatnya.

\section{Metode Penelitian menurut Metode Pelaksanaan}

Terdapat berbagai jenis metode penelitian menurut metode pelaksanaannya. Beberapa jenis dari metode itu dipaparkan secara singkat berikut ini.
Penelitian Survey. Penelitian yang dilakukan dengan mengambil data pada populasi dengan alat pengumpul data berupa kuesioner, wawancara, atau bahanbahan lain yang memberi informasi tentang realitas populasi atau sampel secara faktual, jika populasinya terlalu besar. Data yang diperoleh berbentuk angka (Fink, 2010).

Penelitian Ex Post Facto. Penelitian yang dilakukan dengan cara merunut kebelakang dari sebuah peristiwa tertentu di masa sekarang untuk mencari faktor-faktor yang menjadi penyebab timbulnya peristiwa tersebut. Dapat dilakukan dengan eksperimen atau dengan survey.

Penelitian Eksperimen. Penelitian ini berusaha menguji hipotesis terutama menyangkut hubungan antara variabel bebas dengan variabel terikat dalam model penelitian. Hanya saja, peneliti melakukan kontrol dengan menerapkan sejumlah perubahan dalam variabel untuk mengamati dampak yang ditimbulkannya pada variabel lain dan fenomena apa yang ditimbulkan dengan kontrol tersebut (Liu \& Kulacki, 2019).

Action Research. Penelitian yang bertujuan untuk mengembangkan atau menemukan perbaikan kualitas kinerja pada perorangan atau kelompok tertentu. Juga dapat digunakan untuk meningkatkan kualitas subjek yang diteliti. Sering juga disebut penelitian tindakan dan fokus pada kelas atau grup/ kelompok tertentu (Mertler \& Mertler, 2018).

Penelitian Evaluasi. Penelitian yang berfungsi untuk menilai sebuah produk atau kebijakan telah berjalan sebagaimana yang diharapkan atau tidak. Hasil penelitian ini adalah rekomendasi yang bersifat perbaikan atau dukungan atas keputusan yang telah diambil sebelumnya. Penelitian bermanfaat untuk menemukan masalah dari penerapan kebijakan tertentu dan rekomendasi penyelesaiannya sehingga dilakukan perbaikan dan pengembangan yang baru di dalam pelaksanaannya (Welch \& Patton, 1992).

Penelitian Sejarah. Penelitian ini melakukan analisis terhadap kejadian-kejadian yang berlangsung di dalam sejarah (masa lalu) sehingga ditemukan generalisasinya di masa sekarang, dan kenyataan- 
kenyataan sejarah tersebut dapat dipahami atau diterima; sekaligus informasi yang terkumpul dapat digunakan untuk meramalkan masa yang akan datang (Gray, 2009).

Grounded Research. Penelitian ini dilakukan dengan cara induktif dengan menjadikan data sebagai sumber utama teori. Pengumpulan dan analisis data berlangsung bersamaan dan pada umumnya menghasilkan sebuah teori yang substantif dan padat konsep. Data yang diperoleh dalam penelitian ini adalah kenyataan sosial yang berlangsung dilapangan. Teori yang akhirnya dihasilkan dapat memperkokoh, memperluas dan melengkapi teori yang sebelumnya yang telah ada (Rennie, 1998).

\section{Metode Penelitian menurut Waktu Pelaksanaan}

Ada dua jenis penelitian berdasarkan waktu pelaksanaannya. Apabila penelitian tersebut dijalankan dalam satu waktu tertentu dan tidak berkesinambungan, maka disebut Cross-Sectional. Data di dalam penelitian ini hanya diambil sekali dalam sebuah waktu tertentu. Akan tetapi jika data penelitian diambil dalam sebuah periode waktu, berulang dan membutuhkan pengamatan yang panjang dalam pengumpulan datanya maka penelitian berada dalam kategori Longitudinal Research (Rindfleisch, Malter, Ganesan, \& Moorman, 2008).

\section{Pendekatan Analisis}

Penelitian agama sebagai bagian dari social scienceterbuka untuk beberapa desain penelitian yang mengangkat makna, interpretasi dan fenomena. Dalam hal ini terdapat tiga jenis pendekatan yang umum dikenali sebagai metode analisis di dalam penelitian agama, yakni pendekatan kritik (Critical Theory), pendekatan interpretatif (Interpretative Design), pendekatan naratif (Narrative Design) dan pendekatan fenomenologi (Phenomenology Design).

\section{Pendekatan Teori-Kritik (Critical Theory)}

Pendekatan kritik menilai objek atau realitas secara kritis. Metodologinya menekankan pada pengamatan sehingga dengan demikian sangat bergan- tung pada paradigma peneliti sebagai pengamat utama. Nilai-nilai yang ada di dalam diri pengamat ikut menentukan arah analisis. Itu sebabnya pendekatan kritik tergolong metode analisis yang sangat subjektif dan sangat berorientasi pada ideologi yang dimiliki subjek (Mulyadi, Basuki, \& Prabowo, 2019, p. 94). Pendekatan ini lahir sebagai kritik atas pendekatan positivisme yang dianggap tidak bebas nilai di dalam menilai realitas. Osborne memasukkan ini sebagai suplemen di dalam bukunya Spiral Hermeneutika saat membahas masalah interpretasi teks yang tidak dapat dilepaskan dari paradigma yang dimiliki oleh pembaca teks tersebut. Osborne menyebutnya sebagai pendekatan Reader Response Criticism (Osborne, 2006, pp. 583-587).

\section{Pendekatan Interpretatif (Interpretative Design)}

Pendekatan naratif tidak dapat dipisahkan dari interpretasi hermenetik, sebuah analisis tradisional di dalam penelitian agama. Pendekatan ini tidak menerima penafsiran mutlak karena sebuah pengamatan di dalam penelitian dapat melaporkan makna yang berbeda tergantung dari pendekatan yang digunakan di dalam penemuan makna. Hal yang sangat penting dari metode ini adalah wawasan yang menyertai pendekatan hermenetik untuk interpretasi (Mulyadi et al., 2019, pp. 96-97). Jika wawasannya adalah biblikal mana makna teks diangkat sebagaimana teks tersebut berbicara. Akan tetapi jika wawasan hermenetik merupakan kritik sosial, maka makna teks meluas dan menjadi kontekstual bukan pada 'konteks teks' melainkan pada konteks hermeneutiknya atau pada tempat dimana teks tersebut diterapkan secara interpretatif.

\section{Pendekatan Naratif (Narrative Design)}

Pendekatan ini memiliki banyak bentuk di dalam penelitian agama. Dapat dilaporkan dalam beberapa bentuk sebagaimana diusulkan oleh Ghozali sebagai biografi atau life report, dokumen kehidupan, kesaksian, life writing, life histories, oral histories, popular memories, dsb (Ghozali, 2016, p. 418). Sebagai bagian dari salah satu kritik Alkitab (mo- 
dern criticism), penekanan narasi adalah pada aspek sejarah, peristiwa-peristwa yang menyertainya, seting sosial dan orang-orang yang terlibat (Soulen \& Soulen, 2001, p. 120).

\section{Pendekatan Fenomenologi (Phenomenology Design)}

Pendekatan ini memilih gejala atau fenomena sebagai titik tumpu penelitian, sehingga pengalaman manusia menjadi acuan pengamatan. Agama membawa penganutnya ke dalam pengalaman-pengalaman spiritual. Fenomena dari pengalaman-pengalaman itulah yang menjadi fokus penelitian. Smith mengutip Heidegger mengatakan, studi fenomenologi tidak dapat dipisahkan dari orang yang terlibat dan konteks dimana orang tersebut berada (Smith, 2009). Dalam hal ini, studi fenomenologi agama mengarah pada bagaimana pemahaman kea-gamaan terbentuk di dalam sejarah subjek (Petta-zzoni, 2000 , p. 170) berdasarkan apa yang tampak (fenomena) dan cara bagaimana sesuatu menampakkan diri (Mulyadi et al., 2019, p. 109).

\section{KESIMPULAN}

Sebagai sebuah bidang ilmu yang berada di dalam rumpun social sciences, ilmu teologi, terbuka untuk metodologi dan pendekatan kebenaran apapun. Dalam hal kebenaran, terdapat perbedaan yang sangat dikotom. Kebenaran iman tidak dapat digang-

\section{DAFTAR PUSTAKA}

Aaker, D. A., Kumar, V., \& Day, G. S. (2003). Marketing Research (8th ed.). New Jersey: John Wiley \& Sons, Inc.

Booth, W. C., Colomb, G. G., \& Williams, J. M. (2008). The Craft of Research (5th ed.). London: The University of Chicago Press.

Brannen, J. (2005). Mixing methods: The entry of qualitative and quantitative approaches into the research process. International Journal of Social Research Methodology: Theory and Practice, $\quad 8(3)$, 173-184. https://doi.org/10.1080/13645570500154642

Carey, S. S. (2015). Kaidah Kaidah Metode Ilmiah Penduan untuk Penelitian dan Critical Thinking. Bandung: Nusa Media. gu-gugat dengan metodologi apapun. Tetapi kebenaran pengetahuan yang lahir dari proses induksi dan atau deduksi, da-pat diposisikan di dalam rangkaian metode ilmiah. Dengan demikian, kebenaran itu dapat digugat, diperbaharui, dibantah atau dipertanyakan. Oleh sebab itu, sebuah penelitian agama, seharusnya ditempatkan di dalam kebenaran sains daripada kebenaran iman. Dalil-dalil dan temuan empirik di dalam kebenaran iman berada di dalam posisi abstrak. Tetapi dalan kebenaran sains, dalil dan temuan empirik di wilayah penelitian agama (religion research) selalu dapat diukur, di-lihat dan diamati, bahkan digugat.

Poin yang sangat penting di dalam penelitian agama bukanlah perdebatan tentang metode melainkan pokok masalah sebagai titik awal permasalahan penelitian dan sumbangsih yang dihasilkannya. Sebab, pokok masalah apapun, selama ma-salah itu berada di dalam kerangka ilmu pengetahuan, selalu dapat didekati, dibedah, dianalisis dan diteliti melalui pendekatan kualitatif, kuantitatif atau gabungan keduanya.

Agar dapat membebaskan dirinya dari pengaruh kebenaran iman, peneliti perlu merumuskan dengan tepat pokok permasalahan penelitian dan merancang desain penelitian yang tepat sehingga apa yang hendak diteliti tersebut, memang benar-benar dapat diteliti dan diungkap kebenarannya.

Cooper, D. R., \& Schindler, P. S. (2014). Business Research Methods (12th ed.). New York: McGraw Hill Irwin.

Creswell. (2009). Research design: qualitative, quantitative and mixed approaches. Research Design. https://doi.org/10.2307/1523157

Creswell, J. W. (2010). Research Design Pendekatan Kualitatif, Kuantitatif dan Mixed. Yogyakarta: Pustaka Pelajar.

Degeng, I. N. S., \& Darmawan, I. P. A. (2017). Peningkatan Profesionalisme Pendidik Melalui Penelitian Dan Penulisan Karya Ilmiah. In Seminar Nasional Pendidikan Agama Kristen dan call for papers (Vol. 0). Retrieved from http://semnas.sttsimpson.ac.id/index.php/SNP 
$\mathrm{K} /$ article/view/16

Fink, A. (2010). Survey research methods. In International Encyclopedia of Education. https://doi.org/10.1016/B978-0-08-0448947.00296-7

Ghozali, I. (2016). Desain Penelitian Kuantitatif \& Kualitatif. Semarang: Yoga Pratama.

Golafshani, N. (2003). Understanding Reliability and Validity in Qualitative Research. The Qualitative Report, 8(4), 597-607. Retrieved from http://www.nova.edu/ssss/QR/QR84/golafshani.pdf

Gray, D. E. (2009). Research design: qualitative methods. In Doing research in the real world.

Heit, E., \& Rotello, C. M. (2010). Relations between inductive reasoning and deductive reasoning. Journal of Experimental Psychology. Learning, Memory, and Cognition, 36(3), 805-812. https://doi.org/10.1037/a0018784

KBBI. (2017a). Metode.

KBBI. (2017b). Penelitian.

Knopf, J. W. (2006). Doing a Literature Review. PS - Political Science and Politics. https://doi.org/10.1017/S1049096506060264

Kothari, C. (2004). Research Methodology: Methods and Techniques. Vasa. https://doi.org/http://196.29.172.66:8080/jspui/ bitstream/123456789/2574/1/Research\%20Met hodology.pdf

Lawson, A. E. (2005). What is the role of induction and deduction in reasoning and scientific inquiry? Journal of Research in Science Teaching, 42(6), 716-740. https://doi.org/10.1002/tea.20067

Liu, Y., \& Kulacki, F. A. (2019). Experimental design. In SpringerBriefs in Applied Sciences and Technology (pp. 49-63). https://doi.org/10.1007/978-3-030-02616-5_5

Lumintang, S. I., \& Lumintang, D. A. (2016). Theologia Penelitian dan Penelitian Teologis. Jakarta: Geneva Insani Indonesia.

Mackenzie, N., \& Knipe, S. (2006). Research dilemmas: Paradigms, methods and methodology. Issues in Educational Research, 16(2). Retrieved from https://www.mendeley.com/catalogue/research -dilemmas-paradigms-methods-methodology2/

Magnan, S. S., \& Creswell, J. W. (2006). Research Design: Qualitative and Quantitative Approaches. The Modern Language Journal, 81(2), 256. https://doi.org/10.2307/328794

Merriam-Webster Dictionary Online. (2019). Reasearch. Retrieved May 10, 2019, from https://www.merriam-

webster.com/dictionary/research

Mertler, C. A., \& Mertler, C. A. (2018). What is action research? In Action Research Communities (pp. 5-30). https://doi.org/10.4324/9781315164564-2

Mulyadi, S., Basuki, A. M. H., \& Prabowo, H. (2019). Metode Penelitian KUalitatif dan Mixed Method - Perspektif Yang Terbaru untuk Ilmu-ilmu Sosial, Kemusiaan dan Budaya. Jakarta: PT. Raja Grafindo Persada.

Nassaji, H. (2015). Qualitative and descriptive research: Data type versus data analysis. Language Teaching Research, 19(2), 129-132. https://doi.org/10.1177/1362168815572747

Neuman, W. L. (2016). Metodologi Penelitian Sosial: Pendekatan Kualitatif dan Kuantitatif (7th ed.). Jakarta: PT. Indeks.

Osborne, G. R. (2006). The Hermeneutical Spiral (2nd ed.). Downer s Grove, Illionis: IVP Academic.

Pettazzoni, R. (2000). Wujud Suprim: Struktur Fenomenologis dan Perkembangan Historis. In A. Abdullah (Ed.), Metodologi Studi Agama (1st ed.). Yogyakarta: Pustaka Pelajar.

Rennie, D. L. (1998). Grounded Theory Methodology: The Pressing Need for a Coherent Logic of Justification. Theory \&Psychology, 8(1), 101-119. https://doi.org/10.1177/0959354398081006

Rindfleisch, A., Malter, A. J., Ganesan, S., \& Moorman, C. (2008). Cross-Sectional versus Longitudinal Survey Research: Concepts, Findings, and Guidelines. Journal of Marketing Research, 45(3), 261-279. https://doi.org/10.1509/jmkr.45.3.261

Ruane, J. M. (2013). Dasar Dasar Metode Penelitian. Bandung: Nusamedia.

Saebani, B. A. (2015). Filsafat Ilmu dan Metode Penelitian. Bandung: Pustaka Setia.

Silalahi, U. (2018). Metodologi Analisis Data dan Interpretasi Hasil untuk Penelitian Sosial Kuantitatif. Bandung: Refika Aditama.

Slevitch, L. (2011). Qualitative and quantitative methodologies compared: Ontological and epistemological perspectives. Journal of Quality Assurance in Hospitality and Tourism, 12(1), 73-81. https://doi.org/10.1080/1528008X.2011.54181 0

Smith, J. A. (2009). Psikologi Kualitatif: Panduan Praktis Metode Riset. Yogyakarta: Pustaka Pelajar.

Soulen, R. N., \& Soulen, R. K. (2001). Handbook of 
Biblical Criticism. Louisville, Kentucky: Westminster John Knox Press.

Sudaryono. (2018). Metodologi Penelitian. Jakarta: PT. Raja Grafindo Persada.

Vyhmeister, N. J. (2001). Quality Research Papers. Grand Rapids, Michigan: Zondervan.

Walliman, N. (2011). Research and the research Problem. Your Research Project Designing and Planning Your Work. SAGE Study Skills Series, 1(13), 1-56. Retrieved from http://www.sagepub.com/upmdata/40600_9781849204620.pdf
Welch, J. K., \& Patton, M. Q. (1992). Qualitative Evaluation and Research Methods. The Modern Language Journal, 76(4), 543. https://doi.org/10.2307/330063

Winchester, C. L., \& Salji, M. (2016). Writing a literature review. Journal of Clinical Urology, 9(5),

308-312. https://doi.org/10.1177/2051415816650133

Zaluchu, S. E. (2019). Sistematika dan Analisis Data Riset Kuantitatif (3rd ed.). Semarang: Golden Gate Publishing. 